Michiko Mizoguchi • Takashi Tamura • Akiko Yamaki

Eiji Higashihara Y Yoshiko Shimizu

\title{
Genotypes of autosomal dominant polycystic kidney disease in Japanese
}

Received: October 9, 2001 / Accepted: November 9, 2001

\begin{abstract}
Autosomal dominant polycystic kidney disease (ADPKD) is one of the most common hereditary disorders. The prevalence of the ADPKD genotype in the Caucasian and Latin populations has been reported. Here, we used linkage analysis to demonstrate the prevalence of the genotype and the correlation between phenotypes and genotypes among 21 Japanese ADPKD families consisting of 96 individuals and including 57 affected members. Six polymorphic markers, each linked to either the polycystic kidney disease 1 (PKD1) or polycystic kidney disease 2 (PKD2) gene, were used for polymerase chain reaction analysis. Seventeen families $(81 \%)$ showed linkage to $P K D 1$, two families $(10 \%)$ showed linkage to $P K D 2$, and two families did not show linkage to either $P K D 1$ or $P K D 2$. One of the $P K D 1$-linked families was indicated to have different mutations of $P K D 1$ gene in the same family. $P K D$ 2-linked families did not have milder symptoms than PKD1-linked families.
\end{abstract}

Key words ADPKD $\cdot$ Genotype $\cdot$ Linkage study $\cdot$ Polymorphism $\cdot$ PKD1 $\cdot$ PKD2

\section{Introduction}

Autosomal dominant polycystic kidney disease (ADPKD) is one of the most common hereditary disorders. ADPKD is usually adult onset (MacDermot et al. 1998; Watnick et al. 1999). The prevalence of ADPKD in the Japanese population has been estimated as 1/4033 (Higashihara et al. 1998),

M. Mizoguchi

School of Health Sciences, Tokai University, Isehara, Japan

E. Higashihara

School of Medicine, Kyorin University, Mitaka, Tokyo, Japan

M. Mizoguchi · T. Tamura · A. Yamaki · Y. Shimizu $(\bowtie)$

School of Health Sciences, Kyorin University, 473 Miyashita,

Hachioji, Tokyo 192-8508, Japan

Tel. +81-426-920319; Fax +81-426-920319

e-mail: yshimizu@kyorin-u.ac.jp which is much less than among Caucasians. Previous linkage studies showed that approximately $80 \%-85 \%$ of ADPKD families are positively linked to the polycystic kidney disease 1 (PKD1) gene and most of the remainder are linked to the polycystic kidney disease 2 (PKD2) gene (Wright et al. 1993; Bogdanova et al. 1995; Iglesias et al. 1997). Only a few families not linked either to PKD1 or $P K D 2$ have been reported in Caucasian and Latin populations (Daoust et al. 1995; Almeida et al. 1995, 1999; Turco et al. 1996; Ariza et al. 1997). Correlations between genotypes and phenotypes of ADPKD have also been investigated in those populations (Hateboer et al. 1999). Many researchers have suggested that the severity of symptoms is greater in patients with $P K D 1$ than in those with $P K D 2$, but the relationship is still not clear. We performed linkage analysis to demonstrate the distribution of the genotypes and the difference of phenotypes among the genotypes in 21 Japanese ADPKD families.

\section{Subjects and methods}

Patient recruitment. ADPKD families were recruited nationwide through their family doctors at the request of the ADPKD research group, supported by the Ministry of Health and Welfare of Japan. Family members were evaluated ultrasonographically with symptomatic affected subjects showing at least five more cysts bilaterally in the kidneys. Family doctors took blood samples from individuals after obtaining informed consent. Each family in this study included at least two affected members and a minimum of two unaffected siblings, parents, and/or children.

DNA preparation. Genomic DNA was extracted from peripheral blood lymphocytes by standard methods, using phenol/chloroform extraction and isopropanol precipitation.

Polymerase chain reaction and data analysis. To assess linkage to PKD1, two intragenic (KG8, I42) and four other 
markers for $P K D 1$ were used. I42 is a polymorphic marker within intron 42 of the $P K D 1$ gene. This marker has sequences of tandem repeats, for example, between nucleotides 50155 and 50436. KG8 is a microsatellite marker in the $3^{\prime}$ untranslated region of the PKD1 gene (Snarey et al. 1994). Microsatellite markers 16AC2.5, CW2, SM7 are localized within $350 \mathrm{~kb}$ of the PKD1 gene (Harris et al. 1991; Thompson et al. 1992; Viribay et al. 1994). Microsatellite marker D16S521 is located distal to the PKD1 gene (Coto et al. 1995). To assess linkage to $P K D 2$, six markers, D4S231, D4S1534, D4S1542, D4S1563, D4S1544, and D4S414 (Mills et al. 1992), were used. The 5' end of one of the paired primers was labeled with X-rhodamine isothiocyanate (XRITC) and used for polymerase chain reaction (PCR). PCR was performed as reported previously with slight modifications. PCR products were separated electrophoretically on a $40-\mathrm{cm}$ length of $8 \%$ polyacrylamide gel containing $7 \mathrm{M}$ urea at $18 \mathrm{~W}$ for $4 \mathrm{~h}$. Allele patterns were analyzed with an FMBIO 100 fluoro-imager (Takara, Kusatsu, Japan).

\section{Results}

\section{Heterozygosity of $P K D 1$ and $P K D 2$ markers}

Twelve markers used in this study were selected as polymorphic markers. The heterozygosity in the Japanese population was analyzed using genomic DNA from 80 unrelated Japanese individuals. In I42 marker there were five different sizes of alleles and $47 \%$ of the heterozygosities was shown (Table 1). All were indicated to be useful markers for linkage analysis.

\section{Linkage analysis}

Haplotype analyses were carried out in 21 Japanese families using six markers linked to $P K D 1$ and six to $P K D 2$. The families consisted of 96 individuals, 45 males and 51 fe-

Table 1. Heterozygosity of polymorphic markers linked to PKD1 and $P K D 2$ in the Japanese population

\begin{tabular}{llll}
\hline Marker & $\begin{array}{l}\text { Product size } \\
\text { (bp) }\end{array}$ & $\begin{array}{l}\text { Number of } \\
\text { alleles }\end{array}$ & Heterozygosity \\
\hline PKD1 & & & \\
D16S521 & $239-265$ & 7 & 0.54 \\
KG8 & $145-149$ & 3 & 0.46 \\
I42 & $233-310$ & 5 & 0.47 \\
16AC2.5 & $108-134$ & 13 & 0.88 \\
CW2 & $104-128$ & 11 & 0.91 \\
SM7 & $84-102$ & 11 & 0.75 \\
PKD2 & & & \\
D4S231 & $157-169$ & 4 & 0.47 \\
D4S1534 & $136-164$ & 14 & 0.56 \\
D4S1542 & $210-224$ & 4 & 0.36 \\
D4S1563 & $176-200$ & 4 & 0.79 \\
D4S1544 & $112-120$ & 3 & 0.45 \\
D4S414 & $222-236$ & 5 & 0.63 \\
\hline
\end{tabular}

PKD, polycystic kidney disease males, including 57 affected members. Three-point linkage analysis was performed between the distal and proximal markers for PKD1 and PKD2 that were informative and located at the most flanking locus in each family. Maximum lod scores are shown for each respective $\theta$ value (Table 2). We determined the genotype by the positive or negative lod scores to the PKD1 or PKD2 markers. Sixteen families showed linkage to $P K D 1$. Two families, $\mathrm{K} 38$ and $\mathrm{K} 84$, showed linkage to $P K D 2$, and three families, K68, K71 and K123, did not show linkage to either $P K D 1$ or $P K D 2$. In family K68, which did not show linkage to either $P K D 1$ or $P K D 2$, only two out of three affected sibs had the same haplotype. The nonsense mutation Q4124X in exon 45 was found only in the two members with the same haplotype, but not in the one with the different haplotype (Mizoguchi et al. 2001). This family was also screened for PKD2 gene mutations, but no mutation was found. Because of the mutation data, family K68 was included in the group of PKD1linked families.

Clinical symptoms and genotypes

Comparative clinical symptoms of 57 affected individuals with $P K D 1, P K D 2$, and non- $P K D 1$ or $P K D 2$ genotypes are shown in Table 3. Forty-nine percent of these individuals were on treatment for hypertension, $39 \%$ were positive for liver cysts, and $23 \%$ were on hemodialysis; $4 \%$ had ischemic heart disease, and $5 \%$ had cerebral hemorrhage. In the PKD1-linked families, 4 out of 20 patients had hypertension in their second decade, and $67 \%$ of the patients had hemodialysis treatment before 60 years of age.

Table 2. Linkage analysis and genotype in 21 Japanese ADPKD families

\begin{tabular}{|c|c|c|c|c|c|}
\hline \multirow[b]{2}{*}{ Family } & \multicolumn{2}{|l|}{$P K D 1$} & \multicolumn{2}{|l|}{$P K D 2$} & \multirow[b]{2}{*}{ Genotype } \\
\hline & $\mathrm{Z}$ & $\theta \max$ & $\mathrm{Z}$ & $\theta \max$ & \\
\hline K5 & 0.301 & 0 & -1.11 & 0.0196 & PKD1 \\
\hline K6 & 0.602 & 0 & -4.00 & 0.0050 & PKD1 \\
\hline K22 & 0.602 & 0 & -4.00 & 0.0050 & PKD1 \\
\hline K38 & -0.947 & 0 & 1.490 & 0.0050 & PKD2 \\
\hline K48 & 0.301 & 0.0178 & -2.48 & 0.0196 & PKD1 \\
\hline K56 & 0.426 & 0 & -3.57 & 0.0990 & PKD1 \\
\hline K60 & 0.301 & 0 & -1.41 & 0.0990 & PKD1 \\
\hline K68 & -2.71 & 0.0178 & -3.14 & 0.0148 & non-PKD1, PKD2 \\
\hline K71 & $-\infty$ & 0 & -1.41 & 0.0990 & non-PKD1, PKD2 \\
\hline K74 & 1.200 & 0 & -2.44 & 0.0148 & PKD1 \\
\hline K79 & 0.602 & 0 & -1.41 & 0.0990 & PKD1 \\
\hline K80 & 1.200 & 0 & -3.70 & 0.0050 & PKD1 \\
\hline K84 & $-\infty$ & 0 & 0.113 & 0.0990 & PKD2 \\
\hline K96 & 0.727 & 0 & -2.50 & 0.0196 & PKD1 \\
\hline K97 & 0.903 & 0 & -6.09 & 0.0148 & PKD1 \\
\hline K103 & 0.903 & 0.0178 & -6.80 & 0.0990 & PKD1 \\
\hline K111 & 0.301 & 0 & -1.41 & 0.0990 & PKD1 \\
\hline K113 & 0.902 & 0.0178 & -4.00 & 0.0050 & PKD1 \\
\hline K123 & -0.0512 & 0 & -3.10 & 0.0990 & non-PKD1, PKD2 \\
\hline K127 & 0.726 & 0.0178 & -3.70 & 0.0050 & PKD1 \\
\hline K131 & 0.602 & 0 & -3.04 & 0.0148 & PKD1 \\
\hline
\end{tabular}

ADPKD, autosomal dominant polycystic kidney disease; $Z$, lod score ${ }^{a}$ Two out of three affected members in this family had a nonsense mutation of the PKD1 gene 
Table 3. Distribution of clinical symptoms and genotypes among 57 affected individuals

\begin{tabular}{lllll}
\hline & & \multicolumn{3}{c}{ non-PKD1, } \\
& PKD1 & PKD2 & PKD2 & Total \\
\hline Number affected & $47(100 \%)$ & $5(100 \%)$ & $5(100 \%)$ & $57(100 \%)$ \\
Hypertension & $20(43 \%)$ & $4(80 \%)$ & $4(80 \%)$ & $28(49 \%)$ \\
Liver cyst & $18(38 \%)$ & $3(60 \%)$ & $1(20 \%)$ & $22(39 \%)$ \\
$\begin{array}{l}\text { Hemodialysis } \\
\text { Ischemic heart }\end{array}$ & $9(19 \%)$ & $2(40 \%)$ & $2(40 \%)$ & $13(23 \%)$ \\
$\quad$ disease & $1(2 \%)$ & $1(20 \%)$ & 0 & $2(4 \%)$ \\
$\begin{array}{l}\text { Cerebral } \\
\text { hemorrhage }\end{array}$ & $2(4 \%)$ & $1(20 \%)$ & 0 & $3(5 \%)$ \\
\hline
\end{tabular}

\section{Discussion}

\section{Genotypes in the Japanese population}

The family size in our study was relatively small (average 4.5 individuals). Sixteen of the ADPKD families were positively linked to $P K D 1$. Since a $P K D 1$ mutation was found in family K68, this family was included among those with the PKD1 genotype, so there were 17 PKD1-linked families ( $81 \%)$ among the 21 families. This is almost same proportion of genetic heterogeneity reported previously in other populations, such as among Caucasians (81\%) (Wright et al. 1993), Bulgarians (73\%) (Bogdanova et al. 1993), and Argentinians (91\%) (Iglesias et al. 1997). There has been some doubt about the existence of a third $A D P K D$ gene (Paterson and Pei 1998). Recently, bilineal disease and trans-heterozygotes were found in a large ADPKD family that had been previously assigned to a third PKD-gene linked family. $P K D 1$ and $P K D 2$ mutations segregated independently in this large family (Pei et al. 2001). Family K68 showed the possibility of bilineal ADPKD disease because of different mutations of the PKD1 gene, although only one mutation was identified (Mizoguchi et al. 2001). In family K123, with no linkages to either $P K D 1$ or $P K D 2$, one 11year-old child was affected, but another, 13 years old, was not affected at the time of the study. This child may acquire cysts with age. In the two families (K71 and K123) not linked to either gene, no mutations in the unique region of $P K D 1$ or in exons of $P K D 2$ have yet been identified. Thus, we could not determine whether a third gene for ADPKD is present in these families.

\section{Clinical symptoms and genotypes}

The occurrence of clinical symptoms was lower than reported previously, but patients with hypertension and undergoing hemodialysis treatment showed early onset (Gabow 1993). Eight of the patients in this study were younger than 20 years old, and none had any clinical symptoms at the time of their diagnosis. More individuals may become symptomatic in the future. Differences in the severity of symptoms between patients with PKD1 and those with PKD2 were not clear in this study because only two families were linked to $P K D 2$. But these two PKD2-linked families did not display milder symptoms than the average among $P K D$-linked families.

Acknowledgments We thank Dr. T. Kawamura for the statistical work of the three-point linkage analysis. This study was supported in part by a Grant-in-Aid for Scientific Research from the Ministry of Education of Japan, Project Research Grant of Kyorin University and by a program grant from the Ministry of Health and Welfare of Japan.

\section{References}

Almeida S, Almeida E, Peters D, Pinto JR, Tavora I, Lavinha J, Breuning M, Prata MM (1995) Autosomal dominant polycystic kidney disease: evidence for existence of a third locus in a Portuguese family. Hum Genet 96:83-88

Almeida E, Prata MM, Almeida S, Lavinha J (1999) Long-term followup of a family with autosomal dominant polycystic kidney disease type 3. Nephrol Dial Transplant 14:631-634

Ariza M, Alverez V, Marin R, Aguado S, Lopez-Larrea C, Alvarez J, Menendez MJ, Coto E (1997) A family with a milder form of adult dominant polycystic kidney disease not linked to the PKD1(16p) or PKD2(4q) genes. J Med Genet 34:587-589

Bogdanova N, Dworniczak B, Dragova D, Todorov V, Dimitrakov D, Kalinov K, Hallmayer J, Horst J, Kalaydjieva L (1995) Genetic heterogeneity of polycystic kidney disease in Bulgaria. Hum Genet 95:645-650

Coto E, de Castro S, Aguado S, Alvarez J, Arias M, Menendez MJ, Lopez-Larrea C (1995) DNA microsatellite analysis of families with autosomal dominant polycystic kidney disease types 1 and 2: evaluation of clinical heterogeneity between both forms of the disease. J Med Genet 32:442-445

Daoust MC, Reynolds DM, Bichet DG, Somlo S (1995) Evidence for a third genetic locus for autosomal dominant polycystic kidney disease. Genomics 25:733-736

Gabow PA (1993) Autosomal dominant polycystic kidney disease. N Engl J Med 329:332-342

Harris PC, Thomas S, Ratcliffe PJ, Breuning MH, Coto E, LopezLarrea C (1991) Rapid genetic analysis of families with polycystic kidney disease 1 by means of a microsatellite marker. Lancet 338:1484-1487

Hateboer N, Dijk MA, Bogdanova N, Coto E, S-Malik AK, San Millan JL, Torra R, Breuning M, Ravine D (1999) European PKD1-PKD2 study group: comparison of phenotypes of polycystic kidney disease types 1 and 2. Lancet 353:103-107

Higashihara E, Nutahara K, Kojima M, Tamakoshi A, Ohno Y, Sakai H, Kurokawa K (1998) Prevalence and renal prognosis diagnosed autosomal dominant polycystic kidney disease in Japan. Nephron 80:421-427

Iglesias DM, Martin RS, Fraga A, Virginillo M, Kornblihtt AR, Arrizurieta E, Viribay M, San Millan JL, Herrera M, Bernath V (1997) Genetic heterogeneity of autosomal dominant polycystic kidney disease in Argentina. J Med Genet 34:827-830

MacDermot KD, Saggar-Marik AK, Economides DL, Jeffery S (1998) Prenatal diagnosis of autosomal dominant polycystic kidney disease (PKD1) presenting in utero and prognosis for very early onset disease. J Med Genet 35:13-16

Mills KA, Buetow KH, Xu Y, Weber JL, Altherr MR, Wasmuth JJ, Murray JC (1992) Genetic and physical maps of human chromosome 4 based on dinucleotide repeats. Genomics 14:209-219

Mizoguchi M, Tamura T, Yamaki A, Higashihara E, Shimizu Y (2001) Mutation of the PKD1 gene among Japanese autosomal dominant polycystic kidney disease patients, including one heterozygous mutation identified in members of the same family. J Hum Genet 46:511517

Paterson AD, Pei Y (1998) Is there a third gene for autosomal dominant polycystic kidney disease? Kidney Int 54:1759-1761

Pei Y, Paterson QD, Wang KR, He N, Hefferton D, Watnick T, Germino GG, Parfrey P, Somlo S, St. George-Hyslop P (2001) Bilineal disease and trans-heterozygotes in autosomal dominant polycystic kidney disease. Am J Hum Genet 68:355-363

Snarey A, Thomas S, Schneider MC, Pound SE, Barton N, Wright AF, Somlo S, Germino GG, Harris PC, Reeders ST, Frischauf AM 
(1994) Linkage disequilibrium in the region of the autosomal dominant polycystic kidney disease gene (PKD1). Am J Hum Genet 55:365-371

Thompson AD, Shen Y, Holman K, Sutherland GR, Callen DF, Richards RI (1992) Isolation and characterization of (AC) microsatellite genetic markers from human chromosome 16. Genomics 13:402-408

Turco AE, Clementi M, Rossetti S, Tenconi R, Pignatti PF (1996) An Italian family with autosomal dominant polycystic kidney disease unlinked to either the PKD1 or PKD2 gene. Am J Kidney Dis 128:759-761

Viribay M, Ferreira R, Peral B, Bello D, Ward CJ, Davalos J, Valle C, Harris PC, Castillo DM, Moreno F, Millan JS (1994) Genetic analy- sis of Cuban autosomal dominant polycystic kidney disease kindreds using RFLPs and microsatellite polymorphisms linked to the PKD1 locus. Hum Genet 94:432-436

Watnick T, Phakdeekitcharoen B, Johnson A, Gandolph MA, Wang M, Briefel G, Klinger KW, Kimberling W, Gabow P, Germino GG (1999) Mutation detection of PKD1 identifies a novel mutation common to three families with aneurysms and/or very-early-onset disease. Am J Hum Genet 65:1561-1571

Wright AF, Teague PW, Pound SE, Pignatelli PM, Macnico AM, Carothers AD, De Mey RJ, Allen PL, Watson ML (1993) A study of genetic linkage heterogeneity in 35 adult-onset polycystic kidney disease families. Hum Genet 90:569-571 